\title{
Could shale gas meet energy deficit: its current status and future prospects
}

\author{
Abdul Majeed Shar ${ }^{1}$ Aftab Ahmed Mahesar ${ }^{2} \cdot$ Khalil Rehman Memon $^{2}$
}

Received: 7 November 2016/Accepted: 1 October 2017/Published online: 14 December 2017

(c) The Author(s) 2017. This article is an open access publication

\begin{abstract}
The production of gas from conventional reserves has shown steep decline, whereas the demand of hydrocarbons as energy source is rising. Hence, the resulting deficit of energy can be met by developing the unconventional energy resources. Among all unconventional energy resources, shale gas is relatively the potential source of energy to be developed in a sustainable way. However, the degree of uncertainty is large for sustainable development of shale gas reservoirs. The shale gas found is held in extremely low-permeability formations having poor porosity; the free gas and the adsorbed gas are also found together. Therefore, the production mechanisms of shale gas reservoirs are quiet complex than the conventional gas reservoirs. Hence, the shale gas resources sustainable development remain ambiguous. In order to find sustainable way of exploitation of shale gas resources, this manuscript reviews in detail, the shale gas potential in Pakistan and the world in terms of its distribution, production mechanism, policy implications and development trends.
\end{abstract}

Keywords Shale gas - Sustainable development . Hydraulic fracturing - Status and challenges · Future

Aftab Ahmed Mahesar

engr.aftabmahesar@gmail.com

Abdul Majeed Shar

majeed99pg@gmail.com

1 Petroleum Engineering Department, NED University of Engineering and Technology, Karachi, Pakistan

2 Institute of Petroleum and Natural Gas Engineering, Mehran University of Engineering and Technology, Jamshoro, Pakistan

\section{Introduction}

Pakistan's crude oil production has shown steady decline; however, the demand of energy has resulted in a strong increase due to shifting of population towards urban area on large scale. Pakistan's current annual consumption of oil is only 150 million barrels. During the year 2013-2014, oil consumption increased by $8.9 \%$ (e.g. energy yearbook 2015). Crude oil imports increased by $8.6 \%$, the oil imports cost swelled to 15.50 billion US dollars for year 2013-2014 (e.g. energy yearbook 2015). During year 2015-2016, the imports were also increased to $9.8 \%$ and are estimated to increase further in ensuing years. Pakistan's natural gas production and consumption remained balanced till 2015; however recently, the consumption of gas has shown upward increase to $12 \%$ from 2015 to 2016 and which is the main energy source of the country. Pakistan's present gas demand is of 8 BCFD if it doubles in the next few years, such a up surge in demand of energy can only be met by new discoveries or either importing it. However; Pakistan's future energy will likely be more dependent on the unexploited natural gas reserves, including the tight gas resources and shale deposits (e.g. Annual Statistical Bulletin 2015). Hence, the gas has gained importance as an energy source in the world and in Pakistan as it is found in massive quantity and is less pollutant effluent. The natural gas is in use since last 150 years, mostly as a fuel energy (e.g. Kok and Merey 2014). In the past when gas was produced with oil, it was considered as a nuisance, so some amount of this produced gas was used for the energy supply for the field and the rest was flared. In most of the places, the associated gas was reinjected for pressure maintenance purpose.

The gas as a fuel is more important due to number of reasons. Gas burns more efficiently for power generation; 
relative production of $\mathrm{CO}_{2}$ per unit of electricity generated by natural gas is $50 \%$ less than coal and $30 \%$ less than oil. The heating value of natural gas is much higher compared to other fuels (HC); heating value of gas is around 50.1 MJ/ $\mathrm{kg}$ (e.g. Kumar 2011). Gas is normally cheaper in terms of energy equivalence compared to other fuels such as oil and coal. In meeting steep energy demand of the world, shale gas is the alternative potential energy source to meet the world's energy requirements (e.g. Islam 2014). The shale gas within global gas market will have better capacity of gas to substitute to other fuels. Table 1 shows the conventional gas reserves cumulative volumes that are technically recoverable and are around 14,832 trillion cubic feet (Tcf). However, the increased consumption of gas as a fuel has ensued in concentrating on unconventional natural gas reserves exploitation and sustainable development, particularly the shale gas. In previous decades, the gas production from unconventional reservoirs was not profitable as the reservoirs were confined in extremely lowpermeability formations. However, recent developments in technology and increased gas price all resulted in extraction of gas from unconventional potential e.g. shale gas and tight gas reserves (e.g. Sunjay and Kothari 2011) to provide the nations with cheaper energy and at improved and sustainable supply.

The recoverable shale gas volume presented in Table 1 shows that in all over the world there is around 7795 trillion cubic feet (Tcf) of only shale gas are present. This reported quantity of shale gas is massive in comparison with other unconventional gas reservoirs such as tight gas and coalbed methane. Therefore, the stakeholders, investors have paid their attention on shale gas reservoirs (EIA 2013). From EIA (2013) study shows that the reserves of shale gas are quiet large to meet the world's energy need for future. But the main problem to produce from shale gas reservoirs is that the gas is confined within fine sedimentary rock and has extremely low permeability and poor porosity. However, in recent years, many of the success stories are heard about the shale formations production at profitable rates due to the technological advancement. Hence, it is possible to produce from such reservoirs by use of advanced technology. Drilling horizontal wells and hydraulically fracturing these wells could result in profitable gas production from such low-permeability reservoirs. The first commercial gas production came to existence from shale reservoirs of US which are the result of use of advanced technologies. According to EIA (2015) report, USA is the largest producer of shale gas, the production from shale gas raised to $10 \mathrm{Tcf}$, from $9.5 \mathrm{Tcf}$ in 2012 and it is predicted that it will grow up to $30 \mathrm{Tcf}$ during upcoming years 2040. The production from US shale gas formations will increase from its current production of $40 \%$ in 2012 to $50 \%$ in 2040. Many other countries such as China, Pakistan, Canada, Argentina, and Mexico have shown great interest to invest and to produce from shale gas reserves. Aforementioned countries' E\&P companies and their governments have also initiated research activities for exploitation of shale gas reservoirs.

\section{Shale gas reservoirs characteristics}

The shale states a rock which is composed of small grains of clay mineral associated with quartz; mineral Shale gas is present within the organic-rich fine-grained sedimentary rock (e.g. Suhas 2008). Shale gas is originated within shales/mudstones; however, fine-grained sandstone and siltstone are interlayered with shale or mudstone, and other minerals could also be found in shale formation such as calcite and quartz (Crain 2011).

In shale formations, the gas is found to be present together as adsorbed gas on organic matter and free gas which is present within the fractures or pores. Hence, the shale gases are internally developed reservoirs of continuous petroleum system (e.g. Schmoker 1995) in which shale gas has a poor permeability and porosity could not produce gas at commercial level unless fractured. Shale gas is a dry gas composed of methane $\mathrm{CH}_{4}$ of almost $90 \%$, and it could also be composed of wet gas.

Organic materials buried underneath of earth in shale with temperature and pressure increase transferred into kerogen, which further converts it into oil, and then wet

Table 1 The status of technically recoverable gas reserves around the world Reproduced with permission from EIA 2013

\begin{tabular}{|c|c|c|c|c|c|}
\hline \multirow[t]{2}{*}{ Continent } & \multicolumn{2}{|l|}{ Total } & \multicolumn{3}{|c|}{ Unconventional } \\
\hline & Conventional & Unconventional & Tight gas & Shale gas & Coalbed methane \\
\hline America & 2.401 & 4.414 & 953 & 3.710 & 318 \\
\hline Asia & 5.650 & 3.708 & 989 & 1.840 & 565 \\
\hline Europe & 5.474 & 2.260 & 459 & 883 & 777 \\
\hline Africa & 1.307 & 1.307 & 247 & 1.361 & - \\
\hline Total & 14.832 & 11.689 & 2.649 & 7.795 & 1.660 \\
\hline
\end{tabular}


gas, dry gas (Boyer et al. 2011). Shale formation that holds large quantities of gas is rich in organic material $(0.5-25 \mathrm{wt} \%)$ and contains mature hydrocarbons in the thermogenic gas window, in which high temperature transferred organic material into gas (Ross and Bustin 2008. Shale formations are brittle in nature and are rigid to retain fractures (Ross and Bustin 2008).

Many authors have a reported about the importance and impact of stress towards low-permeability reservoirs on productivity and found that the low-permeability reservoirs such as tight gas sands are very stress sensitive (e.g. Almisned et al. 2017; Shar et al. 2017; Brower and Morrow 1985; McPhee and Arthur 1991; Ostensen 1983). Similarly, the shale gas reservoirs are very low permeable composed of fine-grained sedimentary rock have dual permeability and porosity, e.g. matrix and the natural fractures. Many authors have shown that shale material resides within the nanopores (e.g. Kang 2011). These formations have very small pore less than $2 \mathrm{~nm}$ diameters among these even have less than 2-50 $\mathrm{nm}$ called mesoporous (e.g. Kuila and Prasad 2011). Due to their smaller size pores, existence of natural fractures make these reservoirs very sensitive to stress, with the increase of overburden stress the permeability decrease as well as the productivity of such reservoirs. Hence, it is essential for development of such reservoirs to study the influence of stress to produce on commercial rates.

Shale formations exhibit very low permeability excluding fractures; the permeability is ranging from nanodarcies to microdarcies (e.g. Cipolla et al. 2010). The reservoirs having less than $0.1 \mathrm{mD}$ permeability are said to be unconventional reservoirs (e.g. Law and Curtis 2002). However, the shale gas reservoirs fall within the unconventional category of reservoirs (e.g. Boyer et al. 2011). As the shale gas reservoirs have extremely poor permeability and low productivity could not produce gas at commercial rate, therefore, it is essential to fracture these reservoirs and drill horizontal wells to make these profitable. Hence, the shale gas reservoir can result in profitable gas production with application of advanced technology such as hydraulically fracturing and horizontal drilling (e.g. Sunjay and Kothari 2011). Reservoir management studies are essential for every oil and gas company's project feasibility. Similarly, for shale gas project, profitability assessment prior to any activity such as drilling directional well or horizontal wells and performing fracturing jobs on such low-permeability wells; it is essential to evaluate the shale gas reserves profitability based on their maturity, total organic content, fractions of gas either adsorbed or free present within matrix or fractures, its areal extent and the thickness of the reservoir as well as fluid flow capacity. Aforementioned parameters are the main parameters for shale gas reservoir development (e.g. Boyer et al. 2011). In published literature, authors have reported that commerciality of shale gas reservoir could only be achieved if its porosity and permeability values are greater than $4 \%$ and 100 nanodarcies, respectively. However, the saturation of water should be less than $45 \%$ and the TOC must be greater than $2 \%$, and all above proposed values are critical for shale gas production at profitable level (e.g. Gutierrez et al. 2009).

\section{History of shale gas production}

Gas produced from shale formation of fine-grained sedimentary rock is a potential source of energy. The gas as an energy source has been in use since a century ago. Although the shale gas started producing on commercial scale around a decade ago, when Barnett Shale located in north-central became a commercial realism (e.g. EIA 2011). Production from Barnett Shale gas was the first which resulted in commercial shale production (e.g. EIA 2011). Mitchell Energy and Development Corporation initiated the gas production from Barnett Shale. Later in during 1980s and 1990s, Mitchell Energy investigated a method for productivity enhancement by hydraulically fracturing the Barnett shale (e.g. Salman and Wattenbarger 2011). Hence, several oil companies practiced hydraulic fracturing of shale gas reservoirs. After, year 2000, many other commercial shale gas productions came to exist. Barnett Shale was the first successful example of shale gas production at commercial scale and is providing a production of about 0.50 trillion cubic feet (Tcf) per year of shale gas (e.g. EIA 2015). This has raised expectations to other nations to focus on the domestic production of gas from shale reservoirs to meet their energy deficit. All US shale reservoirs and their production status are shown in Fig. 1, such as Fayetteville Shale, Haynesville, Marcellus, Woodford, Eagle Ford. As the demand for gas as energy sources increased and prices gone up for gas, many other countries have shown interest to increase their domestic gas production from shale formations in order to provide cheaper energy with sustainability. In particular, China has expanded activities for shale gas development (Liu et al. 2015).

\section{Global shale gas scenario}

US indigenous gas production has shown steep increase (Fig. 2); during 1990, the production was $17.8 \mathrm{Tcf}$, and that grown-up to $24 \mathrm{Tcf}$ in 2013, it is also projected that it will hit to 33 Tcf by 2040 (Energy Outlook, A.E. 2013). According to U.S. Energy Information International (IEO 2016) and Annual Energy Outlook 2016 (AEO 2016), the 
Fig. 1 Illustration is the Status of shale gas production from different formation of US shales Source: EIA 2016

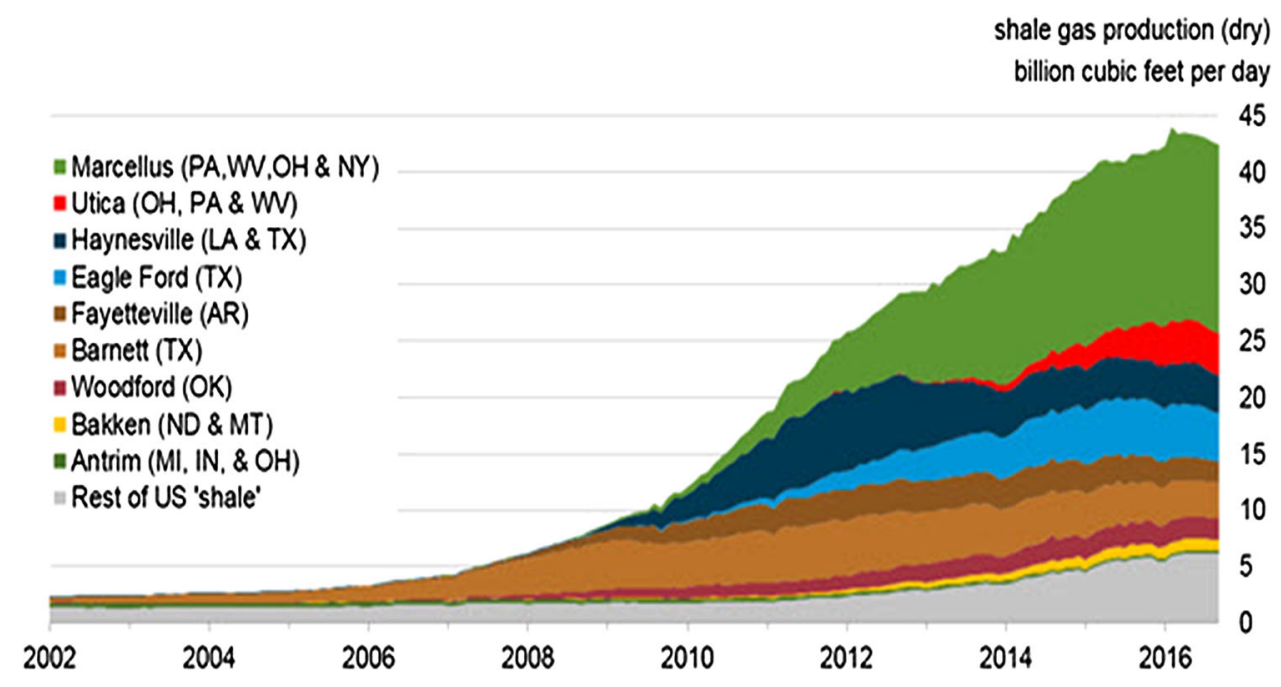

shale gas production (dry)

45 40 35 30 25 20 15 10 5

very limited to invest on their exploration and development (e.g. Cooper et al. 2016).

Even though the infrastructure for Argentina is enough to meet the energy requirement, its commercial production has started and is expected to expand. Algeria's gas production has decreased and is expected to bring its first commercial shale gas production by 2020 . Mexico has projected to commence production from shale gas at commercial level till 2030; the contribution from shale is expected to be more than $75 \%$ of total natural gas production by 2040. As a result, global supply shale gas is expected to be very high in ensuing years. It is expected that shale gas will be the third global energy source by 2035 .

\section{Production mechanisms: shale gas reservoirs}

Gas in shale strata is found to be present as a free gas and adsorbed gas. Knowledge of the pore distribution and pore geometry of shale formation is essential for understanding the flow of gas in such a low-permeability rocks (e.g. Guo et al. 2015). Figure 3 displays the features of gas pore geometry and distribution of shale formation from microto macro-scales. It tells that the free gas is present within the fracture. However, in rock matrixes which are completely filled with kerogen, in which adsorbed gas and free gas are present together (e.g. Guo et al. 2015). Hence, in this complex system, desorption of gas from wall of the pore starts and is flowed towards the matrix system. As the pressure change occurs within the rock matrix and fracture system, transfers of gas take place from matrix to fracture. It has been reported that if there is reduction in reservoir pressure is noticed, then gas desorption phenomena occurs (e.g. Vellanki 1995). Such decrease in reservoir pressure 


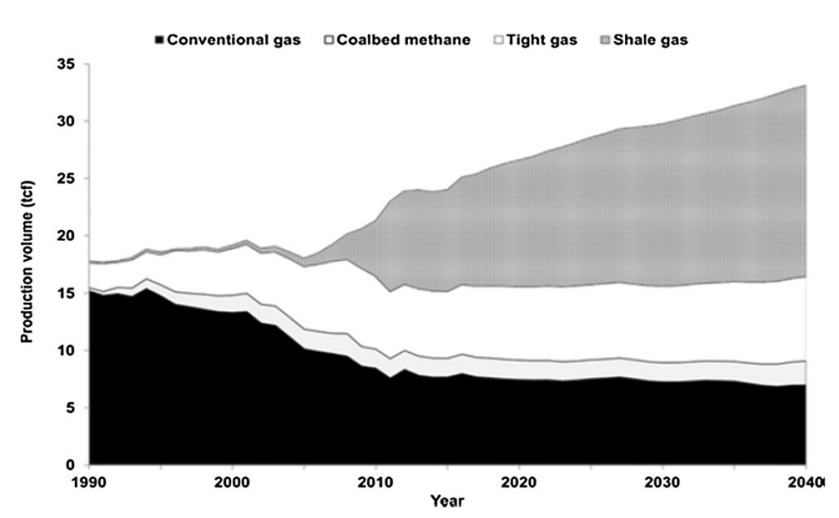

Fig. 2 The illustration is the historical production status of US shale gas past, present and future from 1990 to 2040 Reproduced with permission from EIA 2013 (Cooper et al. 2016)

results in production of free gas and then the adsorbed gas within the pore turn into desorption in a higher capacity (e.g. Salman and Wattenbarger 2011). Once the production from shale gas reservoir begins, the gas from matrix starts transferring towards fractures (e.g. Song et al. 2011). Hence, this causes reduction in pressure, which results in production of free gas through fracture network. Once the production of gas starts, the flow contribution of fracture is high and matrix refills the fractures, and in this way gas flows towards the wellbore and gas is brought to the surface (e.g. Javadpour et al. 2007). However, after pressure depletion, these low-permeability fine-grained sediments may experience pressure sensitivity and reduction in productivity by fracture closure after certain period of production (e.g. Majeed and Mahessar 2016). Hence, it is essential to create fractures for improving the permeability and shale gas reservoirs productivity. More, it also has been reported that the traditional methods of initial in place volumes estimation may result in error as the gas in shale reservoirs is found together with free gas and adsorbed gas (e.g. Lu et al. 1993). Hence, the care must be taken in estimating the in place volumes of shale gas reservoirs.

\section{Shale gas reservoirs hydraulic fracturing}

Shale gas reservoirs exhibit extremely low permeability (e.g. Sunjay and Kothari 2011). In order to produce gas from such low-permeability reservoirs at commercial rate, it is essential to create fracture network. Fracturing results in increasing gas reservoir productivity. Hence, the hydraulic fracturing is the only option to create pores connected and gas can be produced at feasible rates from shale gas reservoirs. Figure 4 provides the simple diagram of the hydraulic fracturing operations in shale gas reservoirs. Hydraulic fracturing jobs are carried out at well sites using heavy equipment including truck-mounted pumps, blenders, fluid tanks, and proppant tanks (Guo 2011). The successful hydraulic fracturing job depends upon the many parameters such accessibility to well, pad construction, drilling and completion of well, casing cementing of well, perforation, completion (Guo 2011). The feasibility of shale gas projects depends on the successfulness of hydraulic fracturing job and other relevant operations.

It is seen from Table 2 shale gas reservoirs are found at 6000-13,000 ft deep or could be deeper than this depth and thin rims of shale formations can be found as the Marcellus shale formation thickness ranges from 50 to $200 \mathrm{ft}$ (AFDC 2014). Therefore, for such thin-rimmed formations with extremely low-permeability rock, it is recommended to

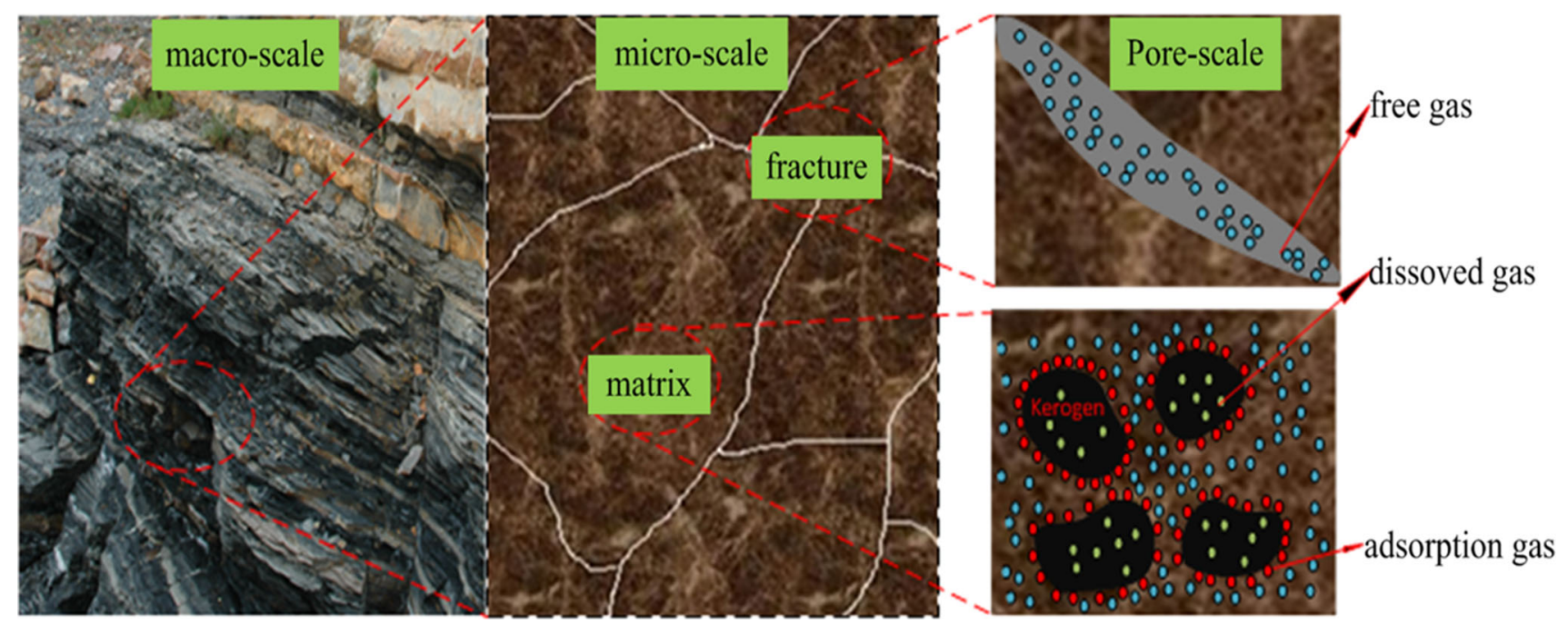

Fig. 3 Gas distributions in shale formation macro-scale to micro-scale. Free gas is found within fractures and adsorption gas is present in the matrix (e.g. Guo et al. 2015) 
Table 2 Pakistan's shale gas reservoir properties Source US EIA Report 2013

\begin{tabular}{|c|c|c|c|c|}
\hline \multicolumn{5}{|l|}{ Basic data } \\
\hline Basin/gross area & \multicolumn{4}{|c|}{ Lower indus $\left(169,000 \mathrm{mi}^{3}\right)$} \\
\hline Shale formation & \multicolumn{3}{|l|}{ Sembar } & Ranikot \\
\hline Geologic Age & \multicolumn{3}{|c|}{ L. Cretaceous } & Palaeocene \\
\hline Depositional environment & \multicolumn{3}{|l|}{ Marine } & Marine \\
\hline \multicolumn{5}{|l|}{ Physical extent } \\
\hline Prospective area $\left(\mathrm{mi}^{2}\right)$ & 26,700 & 25,560 & 31,320 & 26,780 \\
\hline \multicolumn{5}{|l|}{ Thickness (ft) } \\
\hline Organically rich & 1000 & 1000 & 1000 & 1000 \\
\hline Net & 250 & 250 & 250 & 200 \\
\hline \multicolumn{5}{|l|}{ Depth (ft) } \\
\hline Interval & $4000-6000$ & $6000-10,000$ & $10,000-16,400$ & $6000-13,000$ \\
\hline Average & 5.000 & 8000 & 13,000 & 9000 \\
\hline \multicolumn{5}{|l|}{ Reservoir properties } \\
\hline Reservoir pressure & Normal & Normal & Normal & Normal \\
\hline Average TOC (wt \%) & $2.0 \%$ & $2.0 \%$ & $2.0 \%$ & $2.0 \%$ \\
\hline Thermal maturity ( $\%$ Ro) & $0.85 \%$ & $1.15 \%$ & $1.50 \%$ & $0.35 \%$ \\
\hline Clay content & Low & Low & Low & Low \\
\hline \multicolumn{5}{|l|}{ Resource } \\
\hline Gas phase & Assoc. gas & Wet gas & Dry gas & Assoc. gas \\
\hline GIP concentration $\left(\mathrm{Bcf} / \mathrm{mi}^{2}\right)$ & 14.3 & 57.0 & 827 & 17.0 \\
\hline Risked GIP (Tcf) & 45.9 & 174.7 & 310.8 & 54.8 \\
\hline Risked recoverable (Tcf) & 3.7 & 34.9 & 622 & 4.4 \\
\hline
\end{tabular}

penetrate such formation with horizontal drilling for feasible gas production.

\section{Pakistan' Natural gas demand}

Pakistan approximately consumed 4.0 Bcf of natural gas in 2014 , compared to $3.5 \mathrm{Bcf}$ in 2004 . Figure 5 provides the production and consumption trends of natural gas for the past few decade of the country. Pakistan's gas consumption overtook local production after year 2000, when country's population shifted towards urban areas that have resulted in steep increase energy consumption. Prior to this, the developed areas were with limited supply of gas infrastructure. As the population growth has shown steep increase, the demand for electricity is also increased and electricity supply crisis and power planning and policies have been address by various authors (Mirjat et al. 2017; Valasai et al. 2017; Baloch et al. 2017). More recently, it has been reported that a supply and demand gap of the gas has increased due to electricity supply to nation, for power generations. Gas is required as fuel to generate electricity. The demand for natural gas now exceeds $4.5 \mathrm{Bcf} /$ day or
1.6 Tcf/year, with a shortfall of nearly 200 million cubic feet per day. It is expected that this supply gap may last longer, with demand estimated to reach 5 Bcf in 2025 (Fig. 5). The country relies heavily on natural gas for the electricity production, industry running and other energy needs. According to energy year book 2014-2015, gas accounted for $48.3 \%$ of Pakistan's primary energy demand, followed by oil at $32.1 \%$, hydro-electric energy was $11.3 \%$ and coal with a $7.6 \%$ share.

Pakistan's major sectors responsible of the increased gas demand are provided in Fig. 6. Due to electricity shortage, the major gas is consumed in power generating industry. Both the domestic and commercial power generation is expected to increase in the next few years. Unlike India, the growth in power generating industry consumption is notably high and is expected to increase through 2035. Pakistan has planned to generate electricity with help of China Pakistan project called China-Pakistan economic corridor (CPEC). Hence, such national level projects need a massive demand of gas. The shale production will be the only solution as it exists in massive quantity, around more than 9 billion barrels of shale oil also exists (EIA 2017) (Fig. 7). 
Fig. 4 The simple sketch of shale gas reservoir hydraulic fracturing Taken from internet 2016

Fig. 5 Pakistan's natural gas consumption of last few decades Source: BP Statistical Review of World Energy (2017)
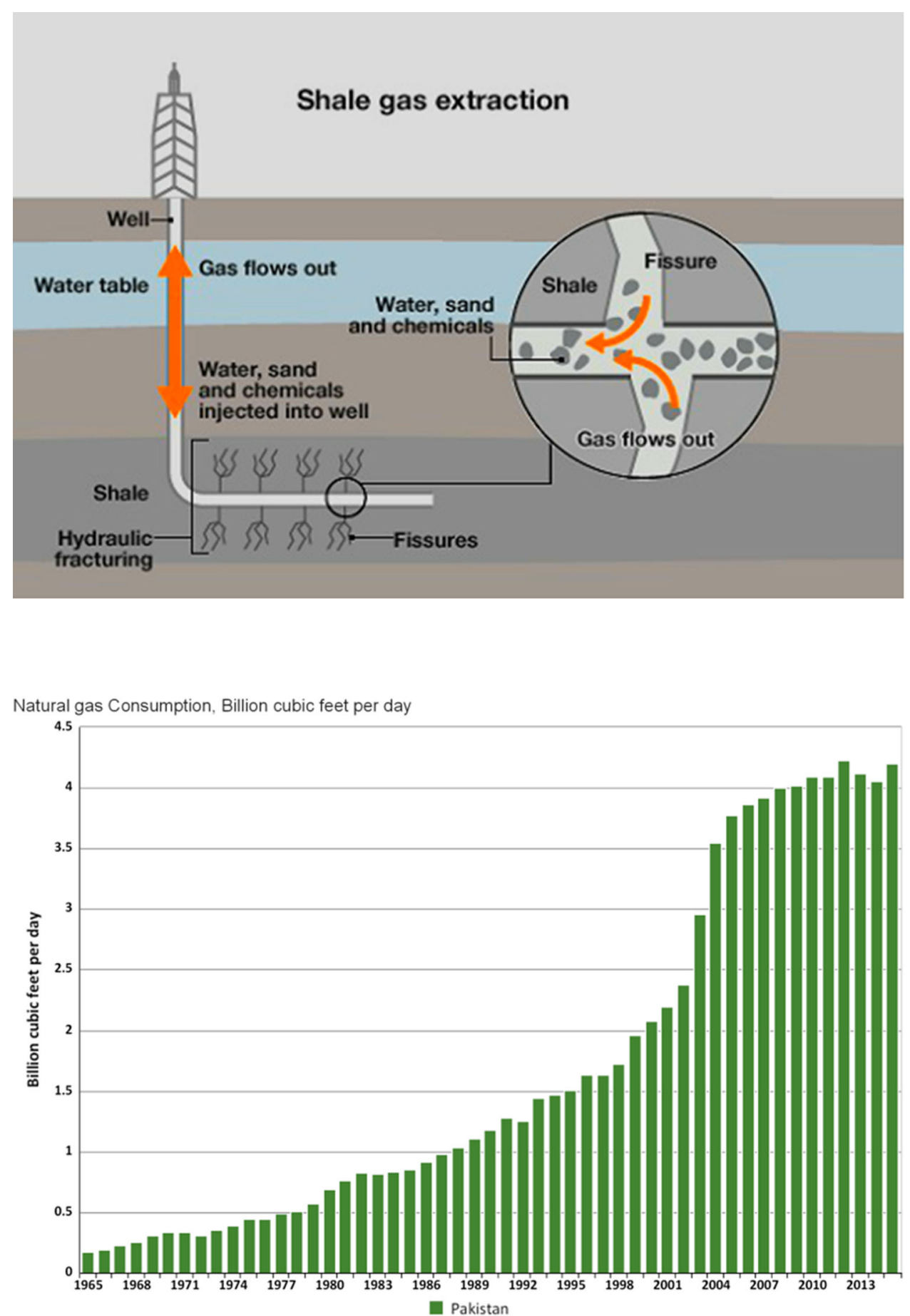

\section{Shale gas prospects in Pakistan and its sustainable development}

Natural gas is the main energy source of Pakistan and is heavily dependent on to meet energy needs. Currently; the demand for gas is around $8 \mathrm{BCFD}$; however, the managed demand is around $6 \mathrm{BCFD}$, while the supply of gas in total is around 4.3 BCF. According to EIA (2013), there an enormous shale gas reserves are present in Pakistan, around $201 \mathrm{tcf}$, trillion cubic feet, of gas is technically recoverable and is reported by the proven studies and verified with technical data. This amount of gas could reduce the country's dependency of gas import from other countries. Pakistan has shale gas potential in Sembar, Ranikot and 


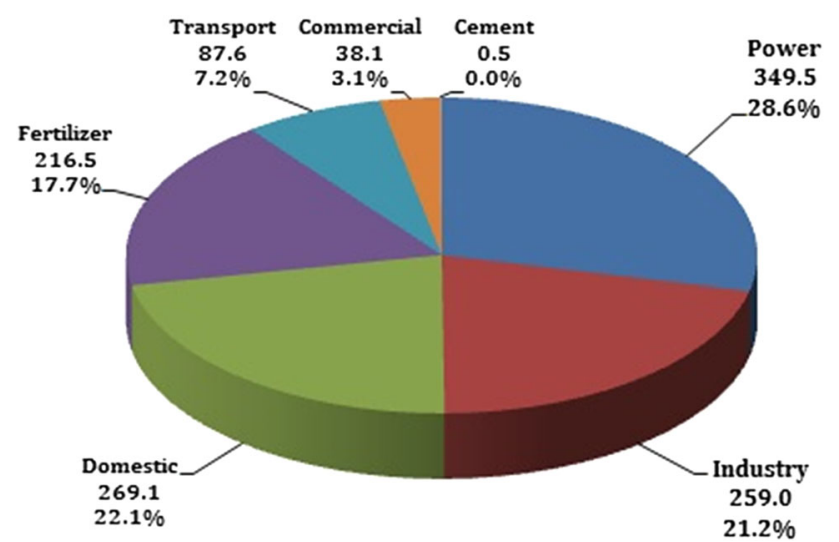

Fig. 6 Pakistan's sector wise gas consumption Sources: HDIP Energy Year Book 2014

Talhar formation in upper and Middle Indus basins of the Pakistan. The shale gas potential of Pakistan and its distribution is shown in Fig. 8. The detailed properties of Sembar and Ranikot shale formation in Indus Basin of Pakistan (e.g. EIA 2013) are presented in Table 2.

The US Energy Information Administration estimates shows that Pakistan has double of shale gas than that of the India is embraced. As reported by US Energy Information Administration, the estimated shale gas of India is about 527 Tcf. However, a detailed assessment of shale gas was initiated in January 2014, in partnership with US Agency for International Development (USAID), the study results revealed that the Pakistan itself has more than 10,000 trillion cubic feet shale gas reserves. These estimated reserves of shale gas are not only higher than the country's conventional reserves (i.e. around 20 trillion cubic feet (Tcf) of gas reserves were estimated and 385 million barrels of oil. Aforementioned estimates of shale reserves are also higher than the estimates of previous years assessed by the U.S. Energy Information Agency (EIA 2014). Based on EIA 2011 report, around 206 Tcf of shale gas exists within lower Indus Basin and it was also mentioned that $51 \mathrm{Tcf}$ could be the technically recoverable. Pakistan shale gas status as assessed by advanced resources international 2013 is presented in Fig. 7.

Pakistan has not yet experienced any major success to produce from its shale gas potential just as in US. In almost all of the basins, Pakistan's shale potential occurs at a depth of 2-6 km; this has resulted in increased cost of drilling. The lack of fracking technologies advancement and its existence in the country is limited to conventional reservoirs fracking and environmental issue yet does not allow to apply these techniques. Hence, poor practices of implementation and the complexities have delayed shale gas production.

The deficiency of a clear framework for awarding shale gas blocks has also hindered exploration and development. Pakistan's Ministry of Petroleum and Natural Resources

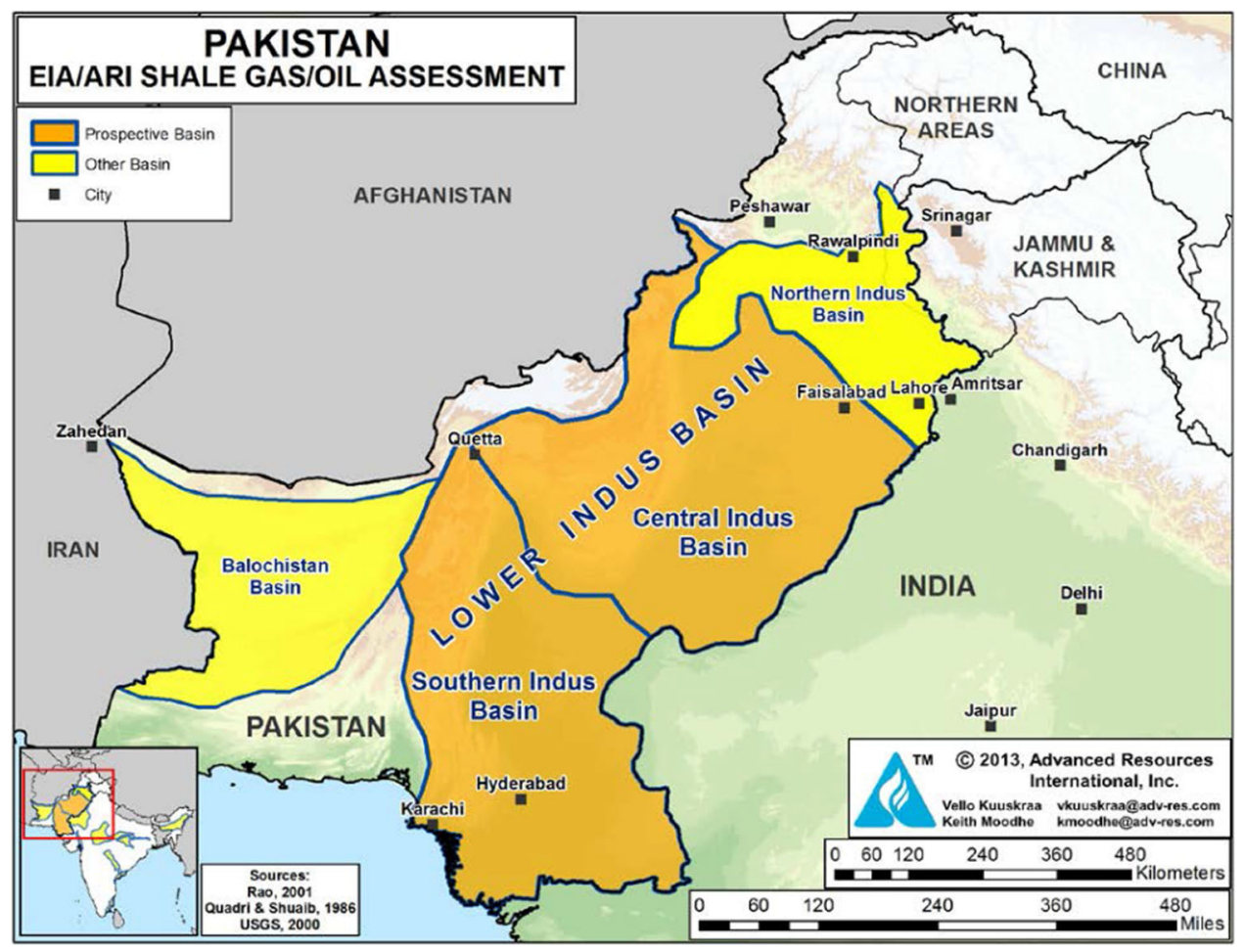

Fig. 7 Pakistan's shale gas status based on EIA and ARI shale gas/oil assessment report Reproduced with permission from ARI 2013 


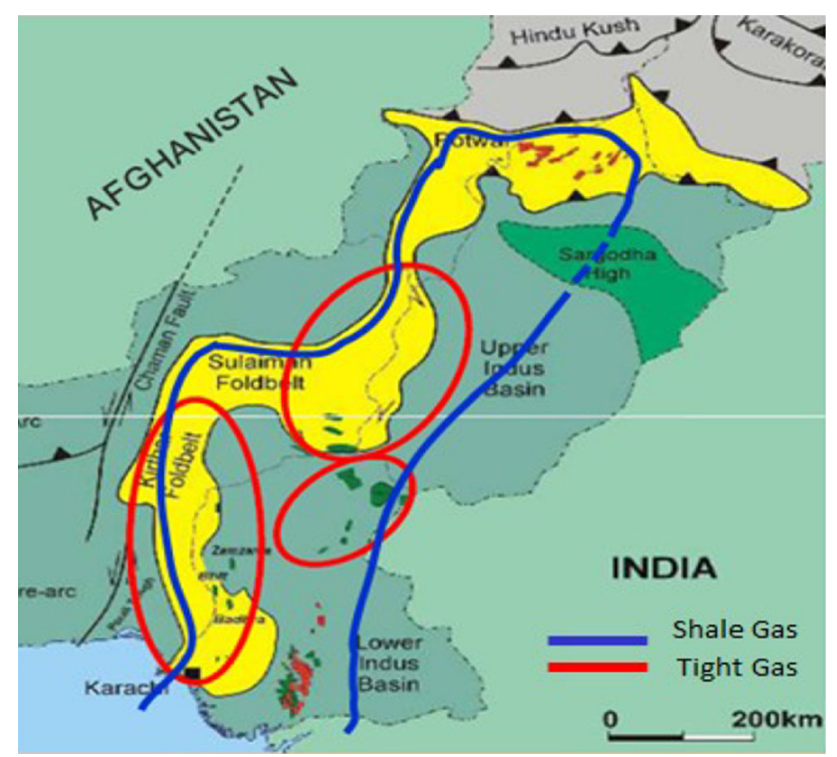

Fig. 8 Pakistan's unconventional resources position, i.e. tight gas and shale gas and total known tight gas sources Pakistan Sources: Eni, OGDCL and OMV Pakistan and Khan 2011

(MNPR) has drafted first Shale Gas Policy. This has to obtain an official endorsement from the Economic CoOrdination Committee (ECC). The key question is then how to motivate Pakistan's national oil companies to spend their capital in exploring and producing gas from shale gas reservoirs. How to justify to stakeholders or national oil companies that shale gas development is feasible. Exempting taxes on some extent, providing subsidies will positively support in meeting the demand of energy and may overcome these problems, concerning to shale gas production.

Pakistan's shale gas reserves of about 105 trillion cubic feet have been reported by EIA's (2013), and these reported reserves are technically recoverable reserves of the country. However, Pakistan's E\&P companies are reluctant to invest their capital on such low permeable reservoirs, as the gas production from tight gas sandstone reservoirs is often marginally profitable; reducing costs is a key strategy for every investor and to improve profitability from such low-permeability reservoirs. For profitability and increased gas recovery from shale gas reservoirs, it is essential for government to provide investors with certain incentives and security for development of shale gas reservoirs. However, the development of such resources is extremely challenging because of instability within the region, difficult to access the locations, the gas prices in Pakistan and key thing is the constraints related to environmental. Although Pakistan has huge amount of shale gas reserves and conventional gas reserves, it has declined steadily over the years. More recently, many national and multinational companies have also made gas discoveries but are not enough to compensate production declines.

Recently, around $\$ 8$ million US dollar has been approved by national oil company, i.e. the OGDCL's board of directors for exploring shale oil/gas reservoirs. The OGDCL oil and gas development company is the key contributor in energy sector of the country with over 1.25 Billion Cubic Feet per Day (BCFD) of gas as well as crude oil with production of 45,000 barrels. The American federal authority on energy statistics and analysis has provided with current estimates of $105 \mathrm{Tcf}$ recoverable shale gas reserves. At present, two state oil and gas companies, Oil and Gas Development Corporation Limited (OGDLC) and Pakistan Petroleum, are carrying out exploration work on one test well to determine the costs involved. Pakistan's Ministry of Petroleum and Natural Resources (MNPR) has designed first Shale Gas Policy (DGPC 2009). This has to obtain an official endorsement from the Economic CoOrdination Committee (ECC). The key question is then how to motivate Pakistan's national oil companies to spend their capital in exploring and producing gas from shale gas, reservoirs. How to justify to stakeholders or national oil companies that shale gas development is feasible. Exempting taxes on some extent, providing subsidies will positively support in reducing the loss of the national companies.

\section{Conclusions}

In conclusion, the energy crisis has become the key issue due to increased gap in demand and supply and could be met by sustainable development of shale gas resources. Because, the shale gas reservoirs exist in sufficient quantity in Pakistan, USA, China, India, Canada and other countries. The literature review confirms the presence of significant shale gas resources within Sembar and Lower Goru formations in the Middle and Lower Indus Basins of Pakistan. Due to the advancement in technology such as fracturing of reservoirs resulted in successful production in USA. Hence, this review suggests that the shale gas sustainable development is possible; however, its future depends on Exploration and production companies to address the all relevant concerns such as environmental, economics, and social aspects.

Specifically, Pakistan is rich in shale gas resources, but the efficient and successful development of shale gas resources requires investments in $R \& D$ that will help in building national level capacity, which in turn decrease the dependency of technology import. In addition, further theoretical breakthrough, strong technological innovation, cost reduction and policy support are essential 
considerations for sustainable development of shale gas resources of the country.

Acknowledgements We are greatly indebted of Mr. Abdul Wahid Shar (Additional commissioner Regional Tax Office, Karachi, Pakistan) for the support provided in preparing this manuscript. Authors are also highly grateful to the anonymous reviewers of the manuscript.

Open Access This article is distributed under the terms of the Creative Commons Attribution 4.0 International License (http:// creativecommons.org/licenses/by/4.0/), which permits unrestricted use, distribution, and reproduction in any medium, provided you give appropriate credit to the original author(s) and the source, provide a link to the Creative Commons license, and indicate if changes were made.

\section{References}

AFDC (2014) Hydraulic fracturing and shale gas production: technology, impacts, and regulations. http://www.afdc.energy. gov/uploads/publication/anl_hydraulic_fracturing.pdf

Almisned OA, Al-Quraishi AA, Al-Awad MN (2017) Effect of triaxial in situ stresses and heterogeneities on absolute permeability of laminated rocks. J Pet Explor Prod Technol 7(2):311-316

Baloch MH, Abro SA, Sarwar Kaloi G, Mirjat NH, Tahir S, Nadeem MH, Kumar M (2017) A research on electricity generation from wind corridors of Pakistan (two provinces): a technical proposal for remote zones. Sustainability 9(9):1611

Boyer C, Clark B, Jochen V, Lewis R, Miller CK (2011) Shale gas: a global resource. Oilfield Rev Autumn 23:28-39

BP Statistical Review of World Energy (2017)

Brower KR, Morrow NR (1985) Fluid flow in cracks as related to low-permeability gas sands. Soc Pet Eng J 25(2):191-201

Cipolla CL, Lolon EP, Erdle JC, Rubin B (2010) Reservoir modelling in shale gas reservoirs. SPE Paper 125530. SPE eastern regional meeting, Charleston, WV, Sept 23-25

Conti J, Holtberg PD, Beamon JA, Napolitano SA, Schaal M, Turnure JT (2013) Annual energy outlook 2013 with projections to 2040. US Energy Information Administration (EIA), Washington

Cooper J, Stamford L, Azapagic A (2016) Shale gas: a review of the economic, environmental, and social sustainability. Energy Technol 4(7):772-792

Crain ER (2011) Unicorns in the garden of good and evil: part 4 shale gas. http://www.spec2000.net/00-publications.htm

Directorate General of Petroleum Concessions-Pakistan (DGPC) (2009) Petroleum exploration and production policy: ministry of petroleum and natural resources, Islamabad, Pakistan, Web accessed 27 Apr 2011

Energy Information Administration (EIA) (2011) World shale gas resources: an initial assessment of 14 regions outside the United States. U.S. Energy Information Administration. http://www.eia. gov/analysis/studies/worldshalegas

Energy Information Administration (EIA) (2013) Technically recoverable shale oil and shale gas resources: an assessment of 137 shale formations in 41 countries outside the United States. http:// www.eia.gov/analysis/studies/worldshalegas/pdf/overview.pdf

Energy Information Administration (EIA) (2014) Annual energy outlook. U.S. Energy Information Administration, Washington

Energy Information Administration (EIA) (2015) Annual energy outlook. U.S. Energy Information Administration, Washington
Energy Information Administration (EIA) (2016) Annual energy outlook. U.S. Energy Information Administration, Washington

Energy Information Administration (EIA) (2017) Annual energy outlook. U.S. Energy Information Administration, Washington

Energy year book of Pakistan (2014-2015). Hydrocarbon development institute Islamabad Pakistan

Guo B (2011) Petroleum production engineering, a computer-assisted approach. Gulf Professional Publishing, Houston

Guo C, Wei M, Liu H (2015) Modeling of gas production from shale reservoirs considering multiple transport mechanisms. PLoS ONE 10(12):e0143649. https://doi.org/10.1371/journal.pone. 0143649

Gutierrez C, Felipe T, Osorio N, Restrepo R, Patricia D (2009) Unconventional natural gas reserves. Energ Núm 41:61-72

Islam MR (2014) Unconventional gas reservoirs: evaluation, appraisal, and development. Elsevier, Amsterdam

Javadpour F, Fisher D, Unsworth M (2007) Nanoscale gas flow in shale gas sediments. J Can Pet Technol 46(10):55-61

Kang SM (2011) Carbon dioxide storage capacity of Barnett shale. M.S. thesis, University of Oklahoma, Norman, OK

Khan (2011) Tight gas unconventional development challenges and pricing issues. PIP-Pakistan energy conference, Petroleum institute of Pakistan 10-12 Apr 2011

Kok MV, Merey S (2014) Shale gas: current perspectives and future prospects in Turkey and the world. Energy Sources Part A Recovery Util Environ Effects 36(22):2492-2501

Kuila U, Prasad M (2011) Surface area and pore-size distribution in clays and shales. SPE Paper 146869. SPE annual technical conference and exhibition, Denver, CO, Oct 30-Nov 2

Kumar A (2011) Adsorption of methane on activated carbon by volumetric method. Master of Technology (Chemical Engineering), National Institute of Technology, Rourkela, India

Law BE, Curtis JB (2002) Introduction to unconventional petroleum systems. AAPG Bull 86:1851-1852

Liu P, Feng Y, Zhao L, Li N, Luo Z (2015) Technical status and challenges of shale gas development in Sichuan Basin, China. Pet J $1-7$

Lu XC, Li FC, Watson AT (1993) Adsorption studies of natural gas storage in Devonian shales. SPE Paper 26632. SPE annual technical conference and exhibition, Houston, TX, 3-6 Oct

Majeed A, Mahesar AA (2016) Pakistan's Kirthar fold belt tight gas reservoirs show development potential. Oil Gas J

McPhee CA, Arthur KG (1991) Klinkenberg permeability measurements: problems and practical solutions. In: Advances in core evaluation IL reservoir appraisal. Proceedings of the 2 nd society of core analysts European core analysis symposium. Gordon and Breach Science Publishers, Philadelphia, pp 371-391

Mirjat NH, Uqaili MA, Harijan K, Valasai GD, Shaikh F, Waris M (2017) A review of energy and power planning and policies of Pakistan. Renew Sustain Energy Rev 79:110-127

Ostensen RW (1983) Micro crack permeability in tight gas sandstone. Soc Pet Eng 23(6):919-927

(2015) Organization of the petroleum exporting countries. Annual Statistical Bulletin," pp 120

Ross DJ, Bustin RM (2008a) Characterizing the shale gas resource potential of Devonian-Mississippian strata in the Western Canada sedimentary basin: application of an integrated formation evaluation. AAPG Bull 92(1):87-125

Ross D, Bustin M (2008b) The importance of shale composition and pore structure upon gas storage potential of shale gas reservoirs. Mar Pet Geol 44:233-244

Salman AM, Wattenbarger RA (2011) Accounting for adsorbed gas in shale gas reservoirs. SPE Paper 141085. SPE middle east oil and gas show and conference, Manama, Bahrain, 25-28 Sept

Shar AM, Mahesar AA, Chandio AD et al (2017) Impact of confining stress on permeability of tight gas sands: an experimental study. 
J Pet Explor Prod Technol 7:717. https://doi.org/10.1007/ s13202-016-0296-9

Song B, Economides MJ, Economides CE (2011) Design of multiple fracture horizontal wells in shale gas reservoirs. SPE Paper 140555. SPE hydraulic fracturing technology conference and exhibition, Woodlands, TX, 24-26 Jan

Sunjay B, Kothari N (2011) Unconventional energy sources: shale gas. In: 10th offshore mediterranean conference and exhibition, Ravenna, Italy, 23-25 Mar
Trading Economics, Pakistan GDP annual growth rate 2016-2017. www.tradingeconomics.com

Valasai GD, Uqaili MA, Memon HR, Samoo SR, Mirjat NH, Harijan K (2017) Overcoming electricity crisis in Pakistan: a review of sustainable electricity options. Renew Sustain Energy Rev 72:734-745

Vellanki SB (1995) Adsorption of binary gas mixtures on wet fruitland coal and compressibility factor predictions. Doctoral dissertation, Oklahoma State University 